The Geneva Papers on Risk and Insurance, 23 (No. 89, October 1998), 490-495

\title{
Will the International Financial Markets Replace Traditional Insurance Products?
}

\author{
by Jürgen Zech*
}

\begin{abstract}
Alternative risk transfer methods are vividly debated these days, with discussions frequently concentrating on technical details. That is quite correct as a generally accepted definition of what constitutes an ART is yet to evolve. There is the tendency, however, not to consider traditional financial reinsurance products as means of an alternative risk transfer since they do not actually entail a genuine passing of the risk to somebody else. Products of this type, such as spread loss, finite risk or multi-year covers, rather provide for the underwriting risk to be distributed to several insurance periods within the balance sheets of the "insured".

In what follows I shall therefore exclusively deal with capital-market products with an insurance link - insurance derivatives and securitization. While the technical aspects and methods and mechanisms of the product design may be interesting, I shall not dwell on them as ART raises one strategically important question: Can capital-market products in the long run be superior to conventional risk transfer products?
\end{abstract}

Nevertheless, it seems appropriate to characterize just some features of these very different products:

- Securitization products are customized. The costs involved are high.

- Insurance derivatives are standardized. The costs involved are low.

In both cases the interest and/or the principle is directly linked to a defined insured loss experience.

\section{The 4 functions}

To my mind, the involved individual transactions which in their entirety constitute a risk transfer by these capital-market products can be divided in four functions:

* Chairman of the Executive Board of Management and CEO, Gerling-Konzern AG, Germany. 
The basic one is the risk management or hedging. What I have in mind here is a risk manager who is looking for capacity or a cost-efficient protection for his risk portfolio and who is trying to explore some alternative solutions. This may be the risk manager of a primary insurance company searching for an alternative to traditional reinsurance markets. Or this may be the risk manager of a reinsurance company looking for an alternative to retrocession, or the risk manager of an industrial company interested in additional or low-priced capacity for specific major risks.

The underwriting comprises the analysis and assessment of a risk or risk portfolio, respectively. Its purpose is to make the risk calculable and thus understandable even to the non-expert. The underwriting function is generally performed by an insurer or reinsurer. But standardization or indexation of risks may also be made by industrial associations or confederations.

Marketing essentially combines two tasks - the first being the product design and the second the canvassing of potential clients as well as the sales activity proper. This function is usually in the hands of banks and brokers but insurance and reinsurance companies may also play an increasingly important role in this field.

The risk carrying is based on the transfer of the risk as the risk is passed on to somebody who is willing to accept it against a risk premium. Risk carriers are generally banks or institutional investors. However, this function may also be assumed by reinsurers.

A graph that I prepared compares the essential characteristics and criteria of the four functions.

The four functions and the attitudes of the players while transferring insurance risks into the financial markets

\begin{tabular}{|c|c|c|c|c|}
\hline & Hedging & Underwriting & Marketing & Risk Carrying \\
\hline Players & $\begin{array}{l}\text { industrial corporation } \\
\text { insurer } \\
\text { reinsurer }\end{array}$ & $\begin{array}{l}\text { insurer } \\
\text { reinsurer } \\
\text { associations }\end{array}$ & $\begin{array}{l}\text { bank } \\
\text { broker } \\
\text { insurer } \\
\text { reinsurer }\end{array}$ & $\begin{array}{c}\text { bank } \\
\text { institutional investors } \\
\text { speculators } \\
\text { reinsurer }\end{array}$ \\
\hline requirements & $\begin{array}{l}\text { mitigate negative } \\
\text { impacts of major } \\
\text { risks, cats }\end{array}$ & $\begin{array}{l}\text { disciplined, thorough, } \\
\text { risk-sensitive }\end{array}$ & innovative, persuasive & $\begin{array}{l}\text { experimental in risk- } \\
\text { taking, } \\
\text { speculative }\end{array}$ \\
\hline qualifications & $\begin{array}{l}\text { analysing \& assessing } \\
\text { the } \\
\text { company's risk } \\
\text { portfolio }\end{array}$ & $\begin{array}{l}\text { experience, decision } \\
\text { making }\end{array}$ & $\begin{array}{l}\text { structuring \& } \\
\text { customizing of } \\
\text { financial products, } \\
\text { access to investors }\end{array}$ & $\begin{array}{l}\text { liquidity, cash, } \\
\text { understanding of risk } \\
\text { economics }\end{array}$ \\
\hline expectations & $\begin{array}{l}\text { capacity } \\
\text { price } \\
\text { continuity } \\
\text { security }\end{array}$ & $\begin{array}{l}\text { fee income, } \\
\text { share of profit } \\
\text { pick and choose }\end{array}$ & $\begin{array}{l}\text { fee income, } \\
\text { client relation }\end{array}$ & $\begin{array}{l}\text { investment } \\
\text { alternative, } \\
\text { high return, } \\
\text { quantifiable risk }\end{array}$ \\
\hline $\begin{array}{l}\text { problems, } \\
\text { obstacles }\end{array}$ & $\begin{array}{l}\text { - new process } \\
\text { - partial coverage } \\
\text { - customized risk } \\
\text { management }\end{array}$ & $\begin{array}{l}\text { - standardization, } \\
\text { indices } \\
\text { - liability risks? } \\
\text { (latency, long-tail) }\end{array}$ & $\begin{array}{l}\text { - packaging/marketing } \\
\text { /accounting costs } \\
\text { - finding suitable deal } \\
\text { \& investor }\end{array}$ & $\begin{array}{l}\text { - lack of experience } \\
\text { - trust in underwriter/ } \\
\text { marketer } \\
\text { - return expectations }\end{array}$ \\
\hline
\end{tabular}




\section{The players}

As we have seen, the four functions can be performed by six different players with varying roles. They are:

- Industrial enterprises

- Primary insurers

- Reinsurers

- Banks

- Brokers

- Institutional investors

During my preparation for this report I talked to representatives of these groups mainly from continental Europe - about their interest in and experience with this new type of risk transfer. Briefly, the response of the individual participants in the type of risk transfer we are discussing has so far been as follows:

- Some major industrial companies are highly interested in the subject and already arranged first meetings with insurers as well as banks and brokers to discuss matters. There have not been any formal agreements by now.

- In Europe, only a few primary insurers have looked at this subject in some depth, and if they did, the main motive was to prepare themselves for discussions with their own clients, the industrial companies. The idea of including these products into their own range of risk management tools has definitely not been in the foreground. Interest is still subdued and no contracts have been agreed.

- All major reinsurers have looked into the matters involved in this subject, albeit to a different extent. The strongest commitment is found with a continental European reinsurer which has set up a special subsidiary in New York.

- With one exception, continental banks are only starting to deal with this subject. There is a certain interest, some staff devote a lot of their attention to these matters; however, no concrete offers have as yet been made or contracts concluded.

- Among the priorities of brokers, this subject has so far ranked way down.

- I would rate the interest of institutional investors in the subject as rather little.

\section{Advantages}

In my judgement the following are the most significant advantages of these new types of products:

- The huge amounts of funds available to worldwide capital markets create a scope of capacity much wider than the one which the insurance industry alone has available. This is the essential contribution which capital-market products may make to the controllability of major risks. In the USA, the capacity of the capital market is estimated to run up to ten times that of the insurance market. Rough capitalization figures are for the US insurance market: $\quad \$ 200$ billion to $\$ 225$ billion the US capital market: $\quad \$ 19$ quintillion or, using the British measure, $\$ 19$ trillion

A comparable ratio would be imaginable for Europe. 
- The new products also make it possible to provide coverage for "multi-risks", including financial risks, such as fluctuations in exchange and interest rates, in addition to normal insurance risks, mainly those arising from fire or natural disaster perils.

- Since investors mostly intend long-term investments, this makes it possible to offer capital-market products and their underlying insurance cover for periods of several years. The insurer's advantage resulting from this is the possibility to calculate risk expenses over a longer term.

- These products may be made available by the capital markets for risk protection at short notice, but they may also be quickly withdrawn. This flexibility is an ideal opportunity to react swiftly to any fluctuation of available capacities and prices in the conventional insurance market.

- For all participants, i.e. the insured, the one who designs the product, and the investor these innovations are intellectually challenging products of a new type, a fact I see as one of their main attractions.

\section{Obstacles}

On the other hand, we must not close our eyes to the disadvantages and problems these derivatives entail. Let me give you a few examples:

- The investor and risk carrier will not generally have adequate experience and the necessary tools available for judging with sufficient accuracy the risk they are taking. The risk assessment may not be a major obstacle in the beginning, as "courageous" investors willing to take a risk and commit themselves to these products may be available in sufficient number. But as soon as the first major series of losses occurs that number is likely to dwindle rapidly.

- Since each individual securitized product has to be newly designed, expenditure incurred will only pay back if amounts invested or loss potentials, respectively, are sufficiently large.

- The products will generally only be suited for those cases where the cause of loss and its amount can be ascertained within a short time after the occurrence of the loss event. Natural disasters or fire losses come to mind as possible areas of applicability. The products are not suited, however, for long-tail business or insurance risks where losses only manifest themselves years after the occurrence giving rise to them. Typical examples of those areas for which the new products are not suitable are product and environmental liability covers.

- Unlike conventional insurance products the capital-market products do not provide for the continuation of insurance protection after the occurrence of a loss event. As soon as the funds available have been consumed, the source of coverage is, for the time being, exhausted. In the traditional insurance market, on the other hand, at least one reinstatement or even several such reinstatements are common practice, giving the insured the good feeling of having coverage available especially in a difficult market environment which not infrequently is brought about by the loss burden resulting from major natural disasters. 
- One of the most important incentives for a risk manager to purchase insurance cover is the service connected with insurance. The experience of, advice and support by the insurer in loss prevention matters and the loss settlement service after the occurrence of an event insured against are rather influential in the decision to take out insurance. These services are, at least on the European continent, an integrated part of insurance protection. The new capital-market products lack such service.

- A risk transfer by means of capital-market products can generally be achieved only in some marginal areas, leaving the basic protection to conventional products, not least so that the insured is able to satisfy his need for service. This division of cover, with good risks being selected and covered via the new-type products also predetermines a tendency to make insurance protection for the remaining risks more expensive and thus less attractive.

- The accounting rules in force do not treat capital-market products as reinsurance. This negatively affects an insurer's solvency.

- Especially with the securitization products I am not convinced that these innovations get along well with the problem of "moral hazard". How will an investor become confident with an insurer's loss and reserve handling? The same problem in the traditional, at least continental reinsurance market has been solved mainly by strong personal ties on the basis of long-standing relations between the market players. In an anonymized capital market this no longer will be a solution to this phenomenon.

- Insurance derivatives are based on a standardization of risk transfer. This is not reconcilable with the efforts made by risk managers to differentiate their risks from those of the competition.

- Finally derivatives are sometimes more difficult to control. Fortunately the worldwide insurance industry could avoid major disasters like Nick Leeson caused to Barings.

\section{Conclusion}

The answer to the question whether capital-market products will push conventional insurance products out of the market is a clear "no", if only because the range of applications imaginable for this type of risk transfer includes, as I see it, less than five percent of the overall insurance volume. Moreover, there is - by now - an unequivocal tendency among all players on the traditional insurance market, i.e. insured, primary insurers and reinsurers, to stick to relations and systems that have grown in years. This is partly due to the fact that conventional insurance has proved its value and its often quite favourable costs over many years.

The long years of good record may be especially significant on the European continent where a long-term partnership between the insured and insurer has always ranked high among priorities. This is not likely to change dramatically, as was confirmed during the talks I had. Furthermore, there is a time gap in progressiveness of at least five years between the more conservative attitude usually taken on the European continent, especially with regard to such new-type products, and the more progressive stance in the Anglo-Saxon and US markets. It would be fatal, however, if continental Europeans failed 
not only to keep a close eye on the trend but also to adjust to these emerging new products.

I view these capital-market products as an essential supplement of conventional insurance products. They are primarily suited for two situations:

- When capacity is required which the traditional market is unable to offer. This situation will be found only very rarely, at least on the European continent.

- When particular developments, that is a massive increase in the number of losses, for example through a series of natural disasters, lastingly disrupts the function of the conventional insurance market. The result may then be a temporary excessive increase in rate levels. If this should happen, alternative products are an excellent means to offer investors additional profit margins.

Taking account of what was said I do not believe that there will be increased competition in this sector between the banks and insurance companies. I would rather expect banks and insurers to join forces for jointly developing and marketing such products and, what is most important, applying them in situations as the ones I just described. 